New Zealand Journal of Industrial Relations, 20(1): 77-92

\title{
COMMENTARY
}

\section{The Employment Contracts Act and Work Stoppages}

\section{Jon Henning*}

\section{Introduction}

A number of important changes in New Zealand's industrial relations have been credited to the effect of the Employment Contracts Act. Among them has been a decline in the level of industrial action, or as Bill Birch has put it, "a dramatic turn-around from the industrial conflict of the past."1 This particular change has been attributed by the Government to the establishment of increased and more constructive communication between employers and employees, no longer impeded by the autocratic and unwarranted interference of old style unionists. ${ }^{2}$

A cursory examination of the main indicators of stoppage activity as measured by the Government indicates the introduction of the Employment Contracts Act in 1991 did indeed coincide with a drop in the level of work stoppages. A little more attention to the detail of the figures available (and with the benefit of a glimpse of hindsight), however, and the coincidence takes on a somewhat different complexion. In particular, the downward trend in industrial activity commenced before the Employment Contracts Act, and the most recent movement in stoppage statistics shows an increase in activity. Together, these suggest that perhaps a little too much too soon has been claimed for the Act.

In brief, the claim that the introduction of the Employment Contracts Act immediately turned around and reduced the level of work stoppages in New Zealand is clearly made from a reading of only a small part of the data available. It also takes a limited view of the influences which can affect work stoppages. The Employment Contracts Act may have been an important change in recent years affecting work stoppage activity, but it has not been the only change. Moreover, there are also several ways in which the Employment Contracts Act could have contributed to a decline in work stoppages. Two of them clearly have little directly to do with the establishment of more harmonious relationships between employers and employees.

* Labour Inspector, Dunedin. The views expressed in this article are those of the author, not the Department of Labour.

Dominion, 26 February 1992: 2.

2 For example W.F. Birch in The Evening Post, 7 January 1992: 5 and The Press, 22 June 1992: 5; NZPD, v.535: 15,052; M McTigue in NZPD, v.534: 14,879 . 
The following analysis of the main stoppage statistics published by the Department of Statistics involves an examination of the frequency and scale (size, duration, monetary cost) of work stoppages in recent years, and considers several reasons for the trends in these data and some implications arising from these developments. ${ }^{3}$ Generally, the findings show that the Employment Contracts Act has had a complex and varied impact on industrial action.

\section{Number of stoppages}

To consider first the number of stoppages, the level did drop dramatically by 48 percent from 137 stoppages in 1990 to only 71 in 1991, and by a further 24 percent from 71 stoppages to 54 in 1992 . From this very low level of stoppages, however, stoppages increased from 54 to 58 for the 1993 year (+ seven percent), and have again increased in 1994. ${ }^{4}$ More importantly, looking back at the data on stoppages prior to 1990 (illustrated in Figure 1), these show that the overall decline in the number of stoppages commenced in the mid 1980s, and that at best the decline in 1991 was an intensification of an existing downward trend in strike frequency. The impressive statistics on the drop in the number of stoppages in 1991 and 1992 can therefore be extended backwards. From 1989 to 1990 the number dropped by 20 percent, from 1988 to 1989 by one percent, from 1987 to 1988 by 11 percent (this was despite the fact that the coverage of stoppage statistics was extended for the first time in 1988 to include the public sector), ${ }^{5}$ from 1986 to 1987 by 10 percent, and from 1985 to 1986 by 44 percent.

Of course the Employment Contracts Act, inconceivably more than a mere twinkle in the eyes of the most farsighted of industrial relations practitioners in 1986, could not be the reason for the decline in the number of stoppages that commenced in that year. Conversely, the factors driving the number down in 1986 may have remained factors in the continuing decline in 1991 and 1992.

\section{Size of stoppages}

The average size of stoppages (number of employees involved per stoppage) for each year since 1960 is illustrated in Figure 2. Looking particularly at the period from 1980, two main features are apparent. The average size of stoppages has tended to fluctuate about a general mean of approximately 450 employees and the range of the fluctuation around this

3 The data and charts used in this paper relating to measures of stoppage activity are based on several data sets which have been assembled using a variety of Department of Statistics source publications. These publications are: Work Stoppages and Industrial Union Statistics: Year Ended December 1985, 1987; and Key Statistics, Hot Off the Press: Work Stoppages, and Labour Market Statistics 19911993 (three annual volumes), all various dates.

4 The latest available data shows that the provisional number of stoppages for the first ten months of 1994 is already 58 , indicating a probable annual increase of the order of between 15 percent to 20 percent over the 1993 year.

s Department of Statistics, Key Statistics, October 1989: 52, note (1) to table 1. 
mean has increased markedly since the late 1980s. Thus, the figure shows that the 1993 result was the lowest average since 1980, but also that the result in 1992 was exceeded in only two of the last 34 years, 1988 and 1991. This latter degree of fluctuation coincides with an expected volatility in data derived from an increasingly small population (in this case, of stoppages taking place).

Figure 1: Number of Stoppages, 1960-1993

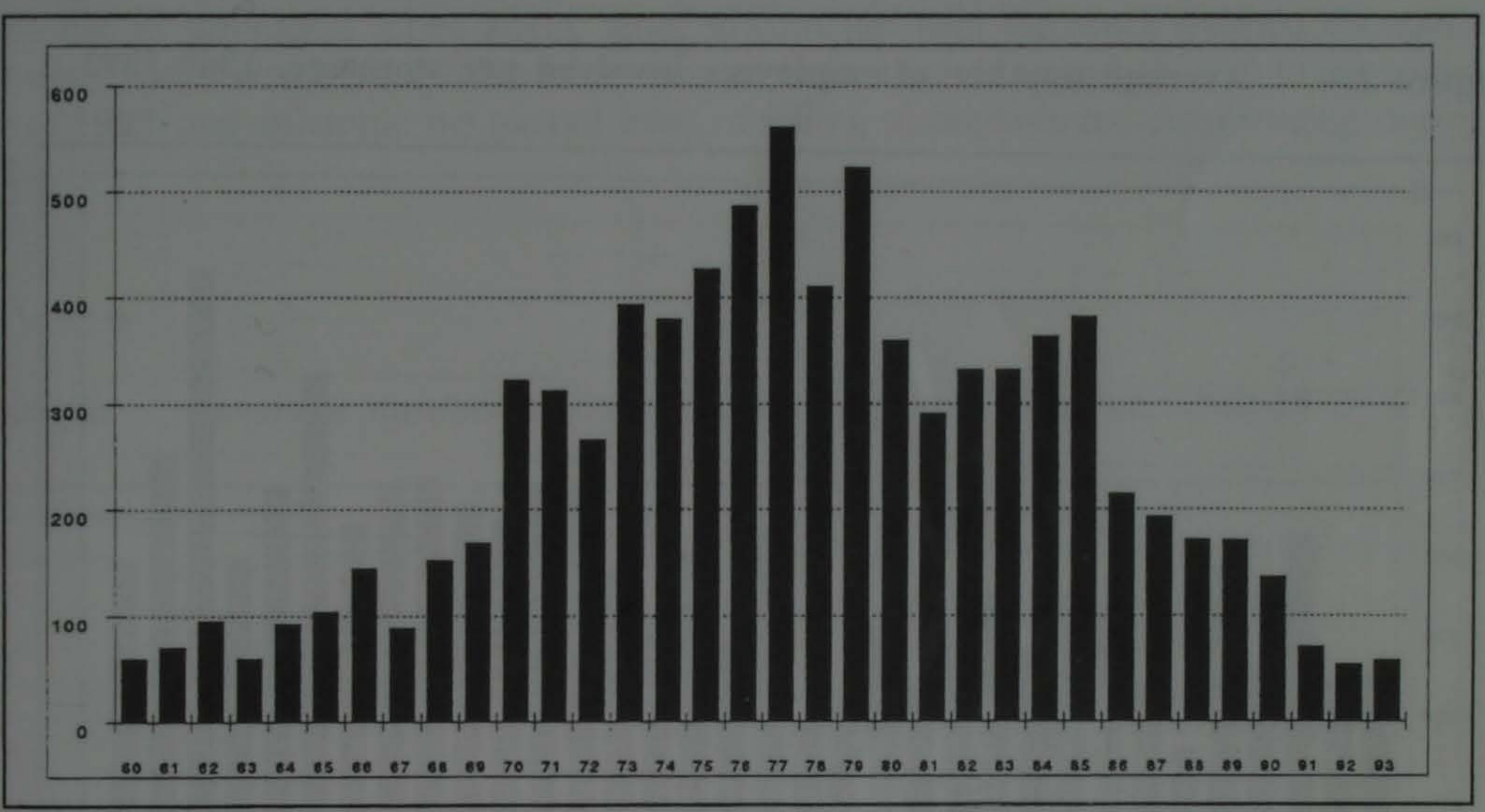

\section{Duration of stoppages}

The general trends for the duration of stoppages (average days lost per employee involved) for the period since 1960 are shown in Figure 3. Although certainly not so marked as the trend in the number of stoppages, it still indicates that the average duration of stoppages has tended to decline since the great peak experienced in 1986. The downward movement has been erratic, again quite probably reflecting the decreasing population of stoppages occurring, and the data show two notable exceptions to the overall trend, 1990 (before the enactment of the Employment Contracts Act) and 1992 (after).

\section{Cost of stoppages}

A final aspect of the scale of stoppages which is indicated in the official statistics, and one which receives some public attention, is the cost of stoppages in monetary terms. In effect, this measure incorporates the combined trends of the number, size, and duration of stoppages, with movements in the average wage of the employees involved.

Like Figure 3, Figure 4 also shows, despite the obvious inconsistencies, something of an overall downward slide in the total loss of wages. This trend, as indicated above, partly 
reflects the composite fluctuations in the average size and duration of stoppages. It also reflects the effect of an erratic but generally upward movement in the average wages of employees involved in stoppage action. Figure 4 indicates the real extent of this upward movement, which tended to move ahead of inflation in the late $1980 \mathrm{~s}$, by the additional illustration of the general increase in average wages of employees involved in stoppages alongside the annual movements in the Consumer Price Index.

Figure 2: $\quad$ Average number of employees involved per stoppage, 1960-1993

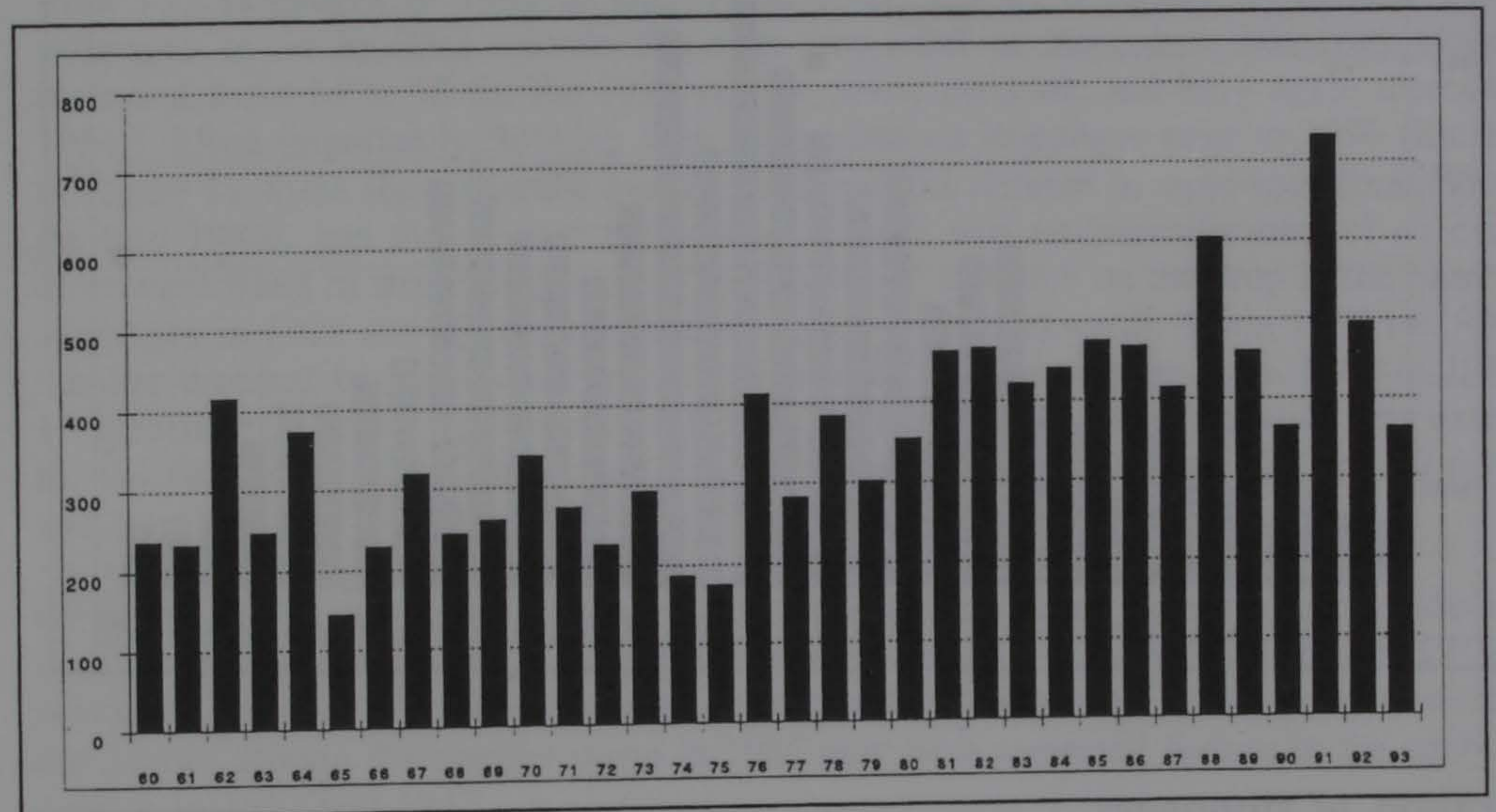

\section{General economic developments}

The data show that the number of stoppages commenced decreasing in 1986, after increasing over the previous four years. They also show that the average size of stoppages does not appear to have changed significantly, the duration of stoppages has tended to decrease, and the average real wages of employees involved in stoppage action have tended to increase since the late $1980 \mathrm{~s}$.

Firstly, what factors may have been responsible for the general decline in the number of work stoppages? It seems most plausible that the initial fall in the number of stoppages in 1986 included the petering out of a rush of activity related to the lifting in 1984 of the wage freeze regulations imposed by the Muldoon Government two years earlier. It is also reasonable to argue that this rise in stoppages, reflecting the release of tensions bottled up by the freeze, may have obscured important developments in the economy which were altering the state of the labour market and which were to have correspondingly more impact on the level of stoppages when the reaction to the freeze lost momentum. 
These developments, which line up reasonably well with the decline in the number of stoppages after 1986, were the stagnation of the economy and decreased job security arising from increasing deregulation in the economy and rising unemployment. ${ }^{6}$ Indexed GDP figures in constant prices from the Department of Statistics show weak and unstable growth for the period from mid-1985 up to the latter part of 1992. Available labour force statistics show significant unemployment growth from late 1987 to early 1989 and then again from late 1989 to a peak in early 1992. The correlation in reverse also works fairly well. The recent rise in stoppages, albeit slight, tends to coincide with the much awaited economic recovery, which now seems to have commenced from around the end of 1992 to the beginning of 1993, and an erratic but overall trend of falling unemployment commencing during 1992.

Figure 3: Average number of days lost per employee involved, 1960-1993

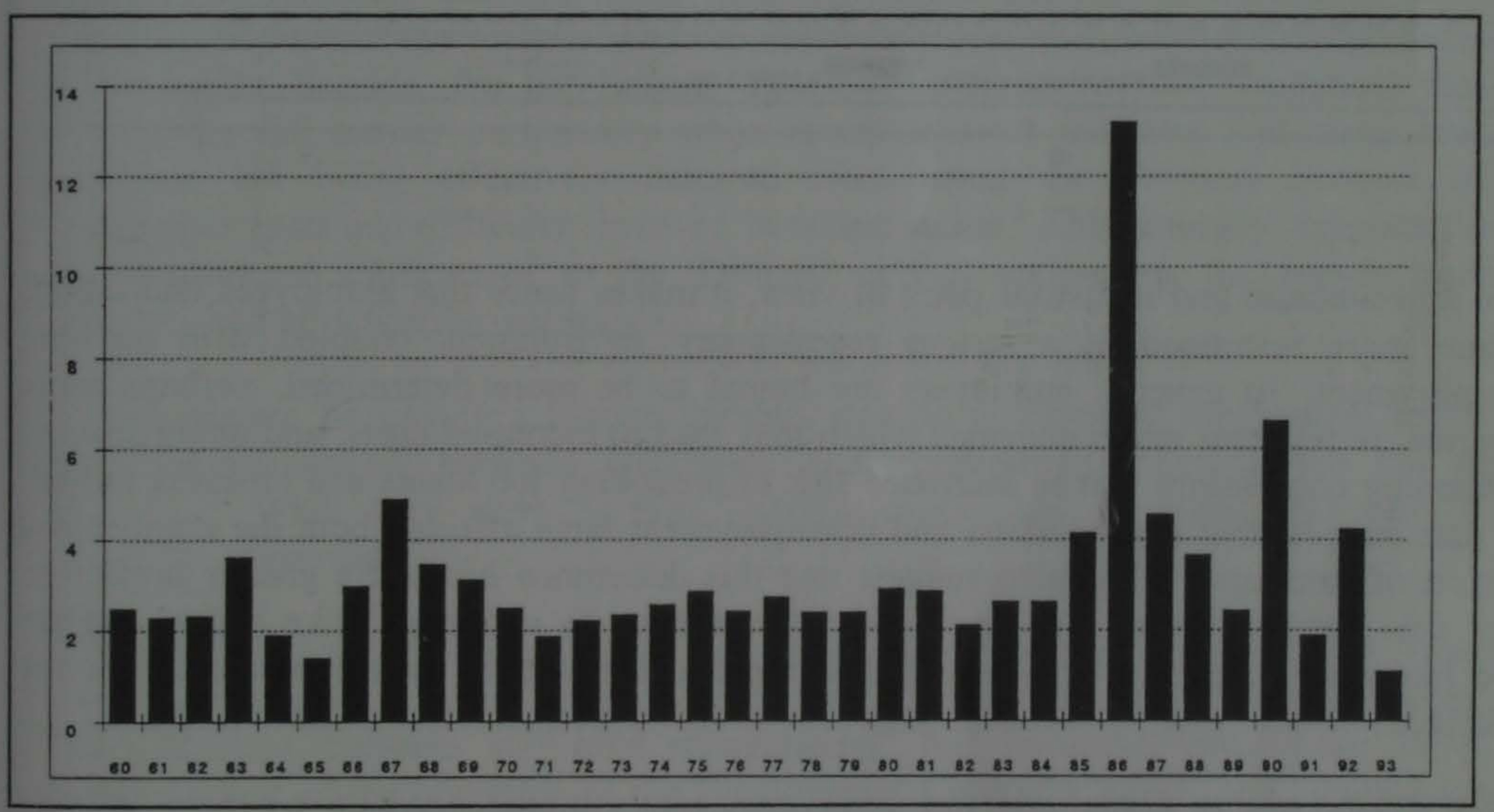

6 Department of Statistics: Key Statistics, various dates; New Zealand Labour Force, various dates. 
Figure 4: $\quad$ Estimated loss in total wages (\$M), wages per employer per day, and CPI: 1960-1993

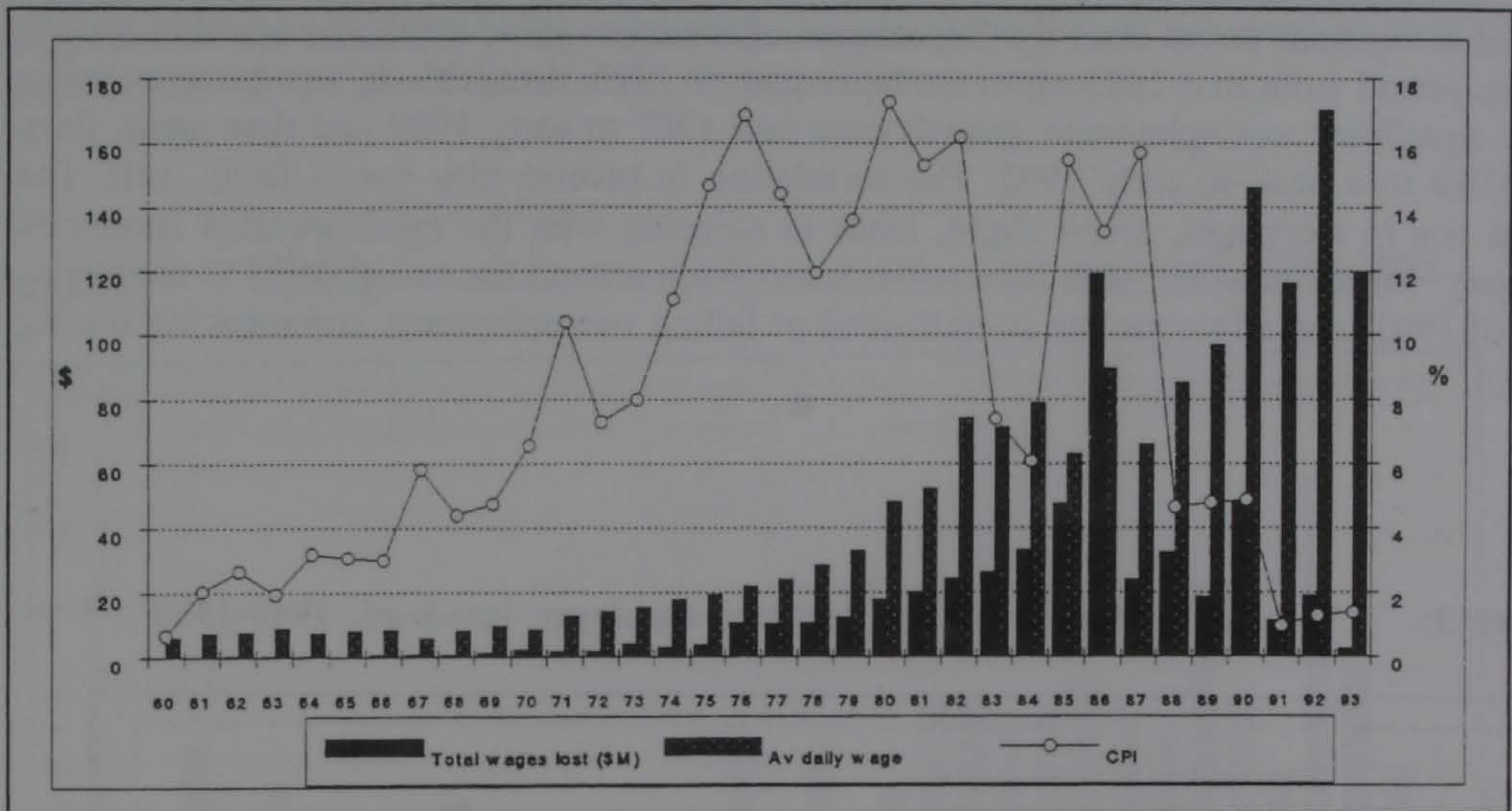

From an economic and industrial point of view, it makes sense that employees and unions became more restrained in a serious recessionary environment coupled with growing unemployment. In general, employers are bound to be more determined, perhaps more desperate, in resisting union demands which may lead to increased costs, and union success in obtaining concessions run an increased risk of provoking job losses and business failure. The data suggest that the recession and unemployment have affected both the number and duration of stoppages. They also suggest that this deterrence has had a greater impact on lower paid workers, who have less financial resources to underpin strike action and are more likely to be poorly skilled and thus more vulnerable to easy replacement in the workplace.

It also seems fair to argue that this discouragement, obvious enough in these adverse economic circumstances, has been strongly reinforced by the vigorous promotion by the Government, particularly the present Government, and the business community of an economic siege mentality and the need to hold and reduce costs as a matter of individual business and national economic survival.

The recession and high unemployment do not seem to have had a corresponding effect on the average size of stoppages probably because the question of whether strikes occur often hinges on obtaining a substantial level of support from the specific workforce to be affected. If such levels are not reached, stoppages are unlikely to occur. Thus, it is the number of stoppages which is necessarily reduced, not their size. 


\section{Changes in employer employee relations}

Macroeconomic determinism, however, does not have to be the exclusive answer which explains the downward trend in the number of stoppages. There is clearly an argument to be made that the Employment Contracts Act has also contributed to the trend. The basis for this argument though is not necessarily that employers and employees are now more likely to be engaged in constructive dialogue. The substantial evidence is that, at best, relations are generally no better under the Employment Contracts Act than they were under the Labour Relations Act.

Firstly, the number of inquiries and complaints to the Department of Labour's Labour Inspectorate has grown dramatically since the Employment Contracts Act was introduced? At a minimum, this suggests a considerably increased employee perception of threat to their basic employment rights and a mistrust of employers' application of these rights.

There has been a similar growth in the number of claims which have been lodged with the Employment Tribunal, although it has been argued that this growth reflects an expansion of the jurisdictions of the Tribunal and Employment Court over those of their predecessors, the Mediation Service and the Labour Court. ${ }^{8}$ One must be rather sceptical that this provides the full answer particularly when recent research indicates that many low paid employees are being effectively deterred from using the Tribunal because of the considerable costs and difficulty involved in taking action. ${ }^{9}$ This naturally suggests that the large number of applications to the Tribunal in fact understates the current need for mediation and adjudication assistance.

The Department of Labour's Heylen surveys also do not support the general thesis that better communication between employers and employees is behind the fall off in stoppages. ${ }^{10}$ What they show is that communication has increased, not that it has necessarily improved.

In 1992, when the first Heylen survey was conducted, between 26 percent and 30 percent of employees agreed with the proposition included in the survey questionnaire that "communication between staff and management" has increased since May 1991 (the commencement of the operation of the Employment Contracts Act). Thus 70 percent to 74 percent agreed that communication had not changed or had decreased. The 1993 follow-up

NZPD: Question Supplemẹt, v.16: 6,286-87.

8 ibid, p.6,715; NZPD, v.535: 15,057

9 Lorraine Skiffington, "Compensation for Unjustified Dismissal under the Employment Contracts Act 1991", Employment Law Bulletin, Butterworths, July 1994.

${ }^{10}$ The figures and detail used below relating to the Heylen surveys were obtained from: Department of Labour, A Survey of Labour Market Adjustment under the Employment Contracts Act, 1991, 1992: 4849 and Appendix C: 16; and A Survey of Labour Market Adjustment under the Employment Contracts Act, 1991 (November 1993), 1993: 38, 81, and Appendix C: 18. 
survey showed that 31 percent agreed that communication had increased, 52 percent agreed it had not changed, and 16 percent agreed it had decreased. On balance, therefore, employees believe that communication has increased since the Employment Contracts Act. Employer support for the proposition was considerably more emphatic. Between 35 percent and 56 percent in 1992 and 61 percent and 75 percent in 1993 (in terms of employee coverage) agreed that communication had increased.

An increase in communication is not necessarily an improvement in communication however. The Heylen surveys also revealed that in terms of trust between employees and management, between 11 percent and 12 percent of employees believed it had increased in 1992 , i.e. 88 percent to 89 percent believed it was unchanged or had decreased since the Employment Contracts Act came into force. In 1993, 15 percent said there had been no change, and 31 percent said it had decreased. Whatever communication was taking place, and increasing, it was not terribly inspiring industrial relations.

Not surprisingly, the results of the surveys in relation to cooperation show little change under the Act. In 1992, cooperation had increased according to 17 percent to 21 percent of employees, 79 percent to 83 percent thought it had not improved or had decreased. In 1993 , 22 percent thought it had increased, 60 percent indicated no change, and 18 percent reported a decrease. " Suggestive in itself of significant miscommunication, employers disagreed with their employees and indicated far higher levels of increased cooperation and, of course, employee trust in their management.

Taken together, can this mean that communication between employees and employers is now better and more constructive under the Employment Contracts Act? There is evidently more, but it appears likely to be largely one way traffic with employers doing most of the talking. It seems difficult to argue strongly that stoppages have fallen as a result of the beneficial effect the Employment Contracts Act has had in bringing employers and employees closer together, simply because the general survey and institutional evidence available suggests that improved relationships of this sort are not being established to a significant extent.

Alternatively, is it probable that, although the increase in communication is largely directive rather than consultative, this increase has had a beneficial impact in reducing stoppages because it has (perhaps in some mysterious way) led to the provision of improved conditions of employment or resulted in a better appreciation amongst employees of employers' actions and the reasons why improved conditions cannot be provided? In general terms, the answer to both parts of the question is no. The Heylen surveys show that employees have less job security, are working harder, and that their terms and conditions

11 The confidence limits set out by Heylen for its second survey were between 18.2 percent and 21.8 percent for a reading of 20 percent: Department of Labour, 1993, Appendix A: xix. 
of employment have changed but not necessarily improved. ${ }^{12}$ They also show, as already discussed, that employees are now less trusting of their employers.

\section{Decline of unions}

A second reason, which provides perhaps a stronger basis for explaining how the Employment Contracts Act may have contributed to a reduction in the level of stoppage activity, is the overall impact of the legislation on the level and quality of union organisation. Strike action, still by far the largest component of stoppage action, usually requires considerable organisation and solidarity between employees if it is to be effectively undertaken. This glue has traditionally been supplied by unions which as a group has suffered a substantial decline under the Act.

Raymond Harbridge and Kevin Hince ${ }^{13}$ have calculated that union membership fell from 603,118 in May 1991 to 428,160 in December 1992. This fall of 29 percent in the level of unionism compares to a five percent decline between December 1985 and September 1989 and a further seven percent decline from September 1989 to May 1991. These decreases up to May 1991 were not negligible, but clearly pale by comparison with the actual impact of the Employment Contracts Act in force. There is little evidence of any significant degree of replacement of unions by other organisations taking advantage of the more liberal representational arrangements possible under the Employment Contracts Act.

There appear to be a number of reasons for this decrease in the level of union membership. Firstly, the decline between 1985 and 1989 can be attributed to restructuring of the economy and rising unemployment - therefore the otherwise paradoxical increase in union density noted by Harbridge and Hince. Also from Harbridge and Hince, the decline from 1989 to 1991 appears to be augmented by the effect of the State Owned Enterprises Act and the State Sector Act in moving a number of employees onto individual contracts, and by an anticipation of the Employment Contracts Act, that is the prospect of voluntary unionism and the breakup of the award based bargaining structure.

The possible reasons for the decline in union membership under the Employment Contracts Act seem numerous. Clearly, given the opportunity under the Act's "freedom of association" provisions, some employees left who had always been unhappy with union

12 Department of Labour, 1992: 29-41 and Department of Labour, 1993: 31-37 and 64-67. The data provided shows that take home rates of pay have increased but that there have also been substantial reductions in other conditions of employment, for example leave and redundancy. The surveys also provide measures of employee "satisfaction" with terms and conditions of employment which the 1992 report acknowledged as surprising and probably indicative of low expectations of the Employment Contracts Act. It is also unclear what constitutes a normal level of "satisfaction" amongst employees (there does not appear to be historically comparable data), and how levels of "satisfaction"/"dissatisfaction" may relate to a propensity for industrial action.

${ }^{13}$ R. Harbridge and K. Hince, "Unions and Union Membership in New Zealand 1985-1992", New Zealand Journal of Industrial Relations, 18(3): 355. 
membership. Some may have also left because they had become disillusioned with the collectivism of the union movement and were reflecting perhaps a growing (or is it cyclical?) enthusiasm for the individualistic ethos espoused by political and business leaders. Some others will have drifted away unattended by unions too busy shoring up core support in larger centres and larger enterprises. ${ }^{14}$

There are also reasons why some employees may have left unions more unwillingly. Unemployment and economic restructuring undoubtedly continued to take its toll. Membership may also have been lost through various combinations of employer discouragement and hostility, and the decline in union services. The latter decline represents a number of problems either directly or indirectly brought on or accentuated by the Employment Contracts Act. These include the ability of employers to render union representation ineffective; the contraction by unions themselves of the provision of services, imposed by the need to husband diminishing resources; and unimpressive bargaining results. ${ }^{15}$ Union membership has also been affected by a relatively common misunderstanding that the Act has somehow eliminated unions.

Through the decline in the membership of unions, particularly since the Employment Contracts Act, a considerable number of employees, now removed from union organisation, are very unlikely to take strike action. For the already disaffected, this possibility was remote in any event. Indeed, such members may have acted as a restraint on their unions' undertaking strike action. There were others, though, who were not necessarily reluctant members and for whom deunionisation has decreased the feasibility of their participation in strikes.

The effect of the drastic decline in membership may have also directly restricted the ability of those who have remained unionists to undertake effective strikes: by reducing the overall control of their unions over the supply of labour available to employers subject to strike action; by reducing their resources (particularly income through the loss of membership) at a time of increasing demands on unions, especially through the need to negotiate a vastly increased number of contracts; and by reducing morale.

It is possible that the general decline in the level of unionism which is shown by Harbridge and Hince may have contributed somewhat to the general fall already noted in the number of stoppages since the mid-eighties. Any effect of this sort, however, would have been strongly magnified with the introduction of the Employment Contracts Act.

14 For example Hector, J. et al., "Industrial Relations Bargaining in the Retail Non-Food Sector: 19911992", New Zealand Journal of Industrial Relations, 18(3): 330-331.

15 Walter Grills, "The Impact of the Employment Contracts Act on Labour Law: Implications for Unions", New Zealand Journal of Industrial Relations, 19(1), passim; Department of Labour, 1993: 71. These factors all contribute to the defection of existing members. Another important factor in the overall decline in the size of unions is the difficulty in organising new members, see Grills, pp.88-89. 


\section{Unlawful stoppages}

Another factor to consider, arising from the introduction of the Employment Contracts Act, is the change in the legislative provisions relating to lawful and unlawful strikes and lockouts.

The clearest aspect of this impact is the removal of the provision, in the Labour Relations Act, which allowed strikes "with the intent to secure a redundancy agreement". ${ }^{16}$ In 1988 , redundancy disputes accounted for 22 percent of all stoppages, 21 percent in 1989, 22 percent in 1990, 10 percent in 1991 (the Employment Contracts Act came into effect in mid-May), but apparently none in 1992 or $1993 .{ }^{17}$

The introduction of the Act also coincided with the general decline in the level of what appear to have often been unlawful stoppages relating to a variety of ad hoc matters. In 1988, the first full year under the Labour Relations Act, the following causes of stoppages were recorded: special payments, two percent; hours of work, one percent; holidays and leave, one percent; managerial practice, one percent; supervisory matters, four percent; work allocation and manning levels, two percent; recruitment and promotions, two percent; working conditions, one percent; sympathy, one percent; demarcation, one percent; other union matters, three percent; political, one percent; personal grievances, two percent; and other, three percent. In total, these represented 25 percent of stoppages by cause. These same issues caused 34 percent of stoppages in 1989, 27 percent in 1990, and 22 percent in 1991. In 1992 and 1993, however, these declined to only 15 percent and 14 percent of total stoppages, respectively.

One possible explanation for this decrease is that some of the disputes under the Labour Relations Act may not have been clearly unlawful, but became so under the Employment Contracts Act, eg. strikes arising from political concerns or "other union matters" during the term of an existing award. Another is that employees and unions, in their weakened state, have become generally more unwilling to commit limited union resources to test employer tolerance of stoppages which are, and have been, without doubt, unlawful, for example in the areas of personal grievances and disputes over the application, interpretation or operation of current employment contracts.

The Employment Contracts Act made two other changes which clearly reduced the likelihood of some specific types of stoppages occurring, but probably with somewhat less impact on stoppage frequency than might initially be anticipated.

The first change involved the removal of the provision available under the Labour Relations Act for lawful stoppage action during the last 60 days of a current document where it

${ }^{16}$ Labour Relations Act, s.233 (1)(d).

${ }^{17}$ It is not entirely clear that redundancy stoppages were not included in the category "other" in the Department of Statistics' release of work stoppages for 1992: Department of Statistics, Labour Market Statistics 1993, 1994: 136. 
related to the negotiation of a substitute document. ${ }^{18}$ The impact of this change is difficult to even start to quantify because data do not appear to be available on the overall level of occurrence of such stoppages under the Labour Relations Act. Nevertheless, it seems likely that a certain reduction in stoppages will have taken place because employees and employers, now prevented from implementing stoppage action during the preliminary period of negotiations under the Employment Contracts Act, will resolve at least some of the disagreements occurring during this time (and which might have flared into industrial action under the old Labour Relations Act regime) before their contract expires. It is also possible, though, that other disagreements will not settle and will still give rise to industrial action once the contract period expires.

The impact of the second change, making stoppages related to the negotiation of multiemployer contracts unlawful, appears on the face of it likely to be substantial. In particular, the restriction clearly eliminated a whole class of stoppages which occurred prior to the Employment Contracts Act in relation to the negotiation of awards. The main effect of the restriction is indirect, however, through the negative impact of the breakdown of the award system on unions, eg. in leading to a reduction in union resources, morale, ability to obtain settlements, and membership. The direct effect of the prohibition on multi-employer strikes is probably not so significant. The crucial issue here is that the prohibition affects the structure of contractual arrangements and that the change redirects, rather than eliminates, negotiation and potential action to the enterprise level. It is hard therefore to argue that this particular restriction should have directly caused any decline in the number of stoppages occurring.

It might also be expected that the restriction on stoppages relating to the negotiation of multi-employer contracts in the Employment Contracts Act should have resulted in a noticeable reduction in the size of stoppages. This expectation is certainly implicit in Bill Birch's remark that "Thanks to the new Act the nationwide strikes that used to be a crippling feature of the New Zealand industrial scene are a thing of the past." ${ }^{19}$ As already shown in Figure 2, however, the average size of stoppages has not clearly fallen. Thus, if there are certainly no multi-employer stoppages now and the average size of stoppages has not significantly decreased as a result of the restriction, multi-employer stoppages are unlikely to have been particularly common prior to the Employment Contracts Act.

This indicates that where unions formerly resorted to industrial action to secure multiemployer documents, particularly in award negotiations, the strategy they used did not generally involve nationwide strikes, or in fact strikes of any substantial breadth, but had as their focus specific action against key individual employers whose positions in disputes were seen as central to achieving required settlements.

It should also be noted that the decline in the duration of work stoppages is not the result of legislative restriction in the Employment Contracts Act. The prospect of Ministerial intervention to bring a lengthy and damaging stoppage to a halt as provided under the

\footnotetext{
${ }^{18}$ Labour Relations Act, s.233(1)(a).

${ }^{19}$ Evening Post, 7 January 1992: 5.
} 
Labour Relations Act, a prospect which itself was the last vestige of a much greater inclination of former Governments towards direct intervention in strikes and lockouts, is now even more restricted under the Employment Contracts Act. ${ }^{20}$

\section{Lockouts}

Much of the thrust of the explanation for the reduction in the level of stoppage action to this point has been to discuss the weakness or unwillingness of employees and unions to embark on strike action. The reason for this is simple: the very large majority of stoppages have been, and remain strikes. It is also true, however, that the decline in strikes, and therefore stoppages overall, has not been reflected in the pattern for lockouts.

In terms of numbers of stoppages, four lockouts were recorded in 1970 and 1971 (only nine lockouts were recorded in the 45 years prior to 1970); five from 1973 to 1975 ; two in 1979 ; seven from 1981 to $1984 ; 15$ from 1985 to 1987 ; and 17 from 1990 to the end of 1993 . The actual numbers of lockouts occurring since the Employment Contracts Act are not clearly greater than they were in the mid-eighties. The proportional analysis illustrated in Figure 5 , though, shows they are now a much more significant element of stoppages overall.

The importance here of this increasing proportion of lockouts is that it tends to verify some key aspects of the explanation for the decline in strikes which have been suggested above. The first of these is that it reinforces the logic of a differential impact from the recession on employees and employers, i.e. that the recession has restricted employees and union expectations but not the drive for employers to alter or reduce conditions of employment.

The increase in lockouts (including the introduction of partial lockouts) ${ }^{21}$ since 1991 , which has been very strongly against the overall trend in the number of stoppages, and the success of such actions, also supports the general perception of employees that employers

${ }^{20}$ Last resort provisions of the sort prescribed in ss.245 to 248 of the Labour Relations Act were abandoned with the introduction of the Employment Contracts Act.

21 The total number of partial lockouts which have been implemented is not entirely clear. Firstly, the number of completed partial lockouts has been included under a general category for lockouts in the published data tables of the official statistics, although the commentary to the 1993 tables revealed separately that three partial lockouts were recorded in 1993. Secondly, as stoppages are only recorded when they are completed, there may be significant delay before partial lockouts, which can (or rather could) often continue for long periods of time, are entered into the official statistics. There must be some additional doubt as to whether the partial lockouts which were still active at the time of the Employment Court's ruling in Witehira v Presbyterian Support Services (Northern), June 1994 (reversing the legitimisation of partial lockouts in Paul vIHC), will, or should, in fact enter the published statistics as work stoppages, even though they were undoubtedly countenanced as a legitimate form of industrial action at the time of implementation. One might further note that there are also long running complete lockouts which may not have been captured by the official statistics to date, most notably the Alliance dispute in Milton. 
have strengthened their industrial position under the Employment Contracts Act, $^{22}$ and hence the employees' position has been weakened. In particular, it appears that employers have not been discouraged at all from taking action under the Employment Contracts Act and the number of lockouts which have occurred and the implementation of partial lockouts give substance to a commonplace interpretation that the Act has allowed employers considerable freedom to explore the boundaries of their authority. ${ }^{23}$ Their relative industrial advantage under the Act seems to stem from the breakdown of the award system and union bargaining rights, which has enabled employers to pick off small groups of employees and to reduce conditions of employment on a piecemeal basis, and the weakness of the unions to oppose such action, including their inability to prevent the employment of non-union labour to undercut resistance to lockout action (as well as strike action).

Figure 5: Lockouts: numbers and percentage of all stoppages, 1960-1993

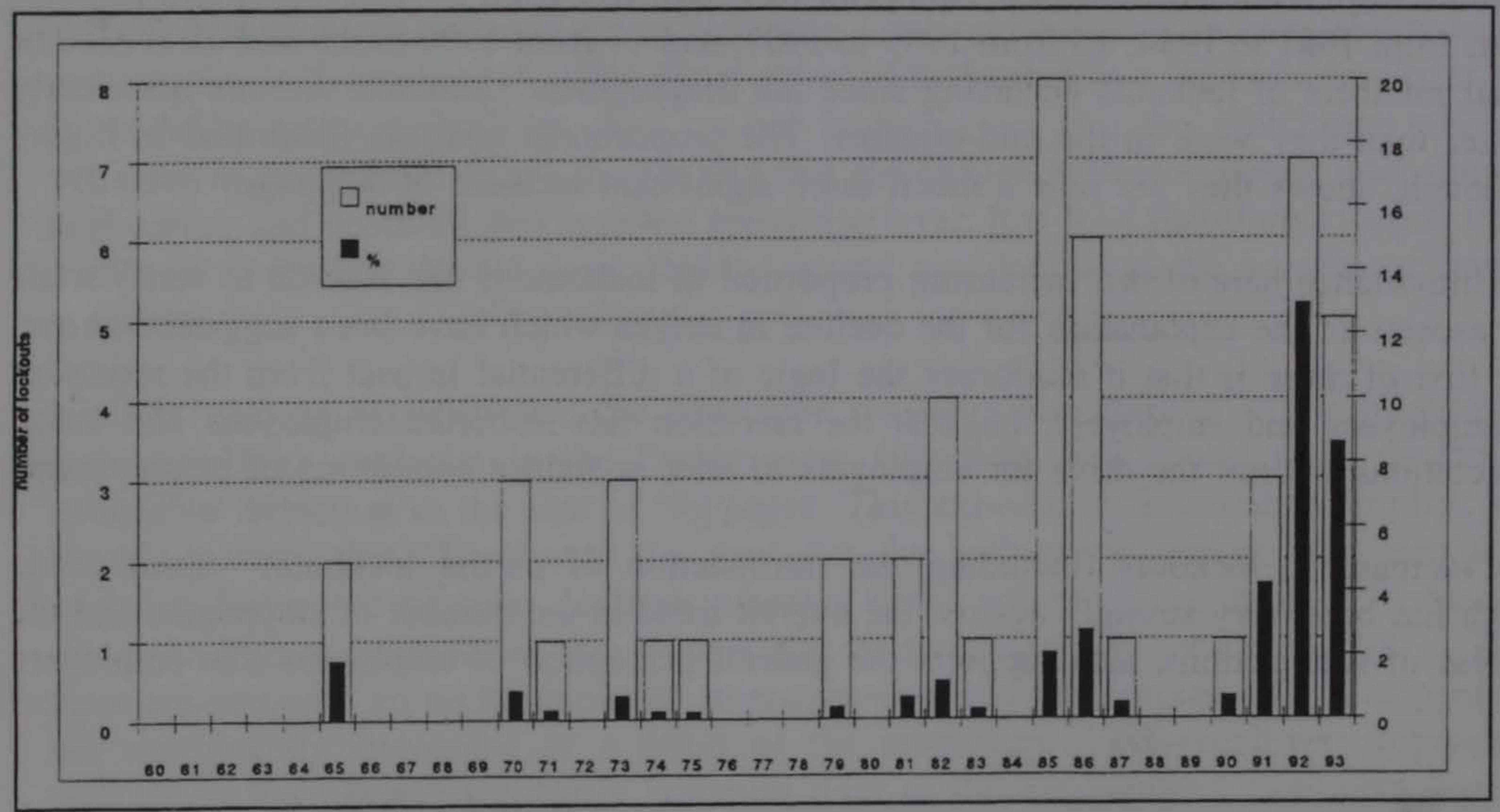

\section{Conclusions}

To summarise, the main features of the trends analysed above are: the decline in the number of stoppages since the mid-1980s, reaching in 1992 the lowest recorded figure for 34 years; a decreasing variety of causes recorded for stoppages since the Employment

22 Department of Labour, 1993: 42.

${ }^{23}$ Another example has been the use of redundancy and the replacement of employees by contractors as per Unkovitch $v$ Air New Zealand Limited, which is discussed in Grills, p.99. 
Contracts Act came into force; the increased numbers of lockouts since the mid-1980s, but most particularly the increased level of lockouts as a proportion of all stoppages since 1991 (with a corresponding decrease in the level of strikes); the lack of any decisive change in the size of stoppages since the introduction of the Employment Contracts Act; a rather erratic shift downwards in the duration of stoppages since the mid $1980 \mathrm{~s}$, and a general rise in average real wages of employees involved in stoppages since the late 1980s.

In considering these features, it should be clear that the view that these changes are the result of an improvement in the harmony of relations between employers and employees arising from the beneficial effect of the introduction of the Employment Contracts Act is not a particularly strong argument. Instead, most of the changes identified in the frequency and scale of work stoppages are more likely to be the result of: economic recession and decreased job security; the negative impact of the Employment Contracts Act on employees and unions and their ability to maintain their organisational strength and to undertake industrial action; and the implementation of new legislative restrictions (on industrial action) in the Employment Contracts Act.

For the sake of clarity, the action of these elements which have been identified as having an impact on the level of stoppages has tended to be described separately. For a more complete picture, however, it would be remiss not to note that these elements are likely to reinforce each other. In particular, the recession, unemployment, and the Employment Contracts Act (with its voluntary unionism provisions, its restrictions on stoppages, and the removal of the underpinnings of the award system) have all probably discouraged employees and weakened the union movement. And, in turn, unions have been less able to take industrial action, either lawfully, or to challenge the legal restrictions of the Employment Contracts Act by making calculated breaches of the Act.

\section{Extrapolating from current trends}

Finally, how are current trends in work stoppages likely to develop? It has already been stated that stoppages rose slightly last year and that this change corresponds to a recent improvement in economic performance and falling unemployment. The inferences that might be drawn from this connection are that employees and their unions are regaining the bargaining leverage and the confidence which makes industrial action both possible and likely to be successful, and that a continuation of the recovery will lead to further increases in stoppages.

A point already laboured in this paper, however, has been the danger of reading too much into a limited set of statistical data and from a narrow view of the reasons behind such changes. Certainly the figures for one year do not form a very reliable basis for establishing a statistical trend. Before leaping to the conclusion that an improving economy will automatically result in an increasing number of stoppages, the possible long term effects of the Employment Contracts Act should also be considered. 
There is no clear indication that the corrosive effect of the Employment Contracts Act on the union movement has halted. A continuing decline in union organisation may further weaken the ability of unions to undertake industrial action, even to the extent perhaps of offsetting the increased opportunities offered by an improving economy. In addition, the restrictions on lawful stoppages in the Employment Contracts Act have not been, and appear unlikely to be, changed. As such they may continue to be an impediment to increased levels of industrial action.

The prognosis for work stoppage activity is therefore uncertain. Whatever the trend, however, the causes will likely be complex and varied, and simple explanations should be treated with some scepticism. ${ }^{24}$

${ }^{24}$ As a matter of historical interest it might also be noted that the Government's claims in relation to the Employment Contracts Act bear a strong similarity to the Liberals' claims around the turn of the last century in relation to the Industrial Conciliation and Arbitration Act. Jim Holt in his authoritative work, Compulsory Arbitration in New Zealand: The First Forty Years (Auckland University Press, 1986: 35 and 52-53), outlined a number of reasons for scepticism over the views of William Pember Reeves and others that the IC\&A Act was responsible for the industrial peace of the late 1890s and early years of the twentieth century, and clearly preferred the critical contemporary analysis of John Macgregor, a Dunedin lawyer who was appointed to the Legislative Council in 1891. The instructive irony which carries with it only the slightest of grains of optimism is that it was the views of Reeves and sympathetic commentators, not the "good deal more insightful" views of Macgregor, which carried the day (at least until Holt's revisionism nearly one hundred years later). 